American Journal of Environmental Sciences 5 (4): 556-561, 2009

ISSN 1553-345X

(C) 2009 Science Publications

\title{
Preliminary Tests Concerning Zero-Valent Iron Efficiency in Inorganic Pollutants Remediation
}

\author{
Silvia Fiore and Maria Chiara Zanetti \\ DITAG-Department of Land, Environment and Geo-Engineering, \\ Politecnico di Torino, Corso Duca Degli Abruzzi 24, 10129 Torino, Italy
}

\begin{abstract}
Problem statement: This study was aimed to a preliminary evaluation of the applicability of granular Zero-Valent Iron (ZVI) to the on site remediation of groundwater polluted by inorganic contaminants by means of a Permeable Reactive Barrier (PRB). A particular interest was devoted to groundwater impacted by Acid Mine Drainage (AMD) that was caused by the oxidation of metal sulphide minerals contained in mine wastes, especially iron disulphide pyrite. Although AMD consequences were particularly evident in surface waters, the percolation through mine wastes may heavily alter the groundwater quality, therefore is particularly important the development of a restrained cost remediation technique for groundwater polluted by AMDs. Approach: In this study the degradation efficiency of Brown size 8/50 ZVI (Peerless Powders and Abrasive Inc., Detroit, US) was evaluated performing a leaching column test and analyzing the Oxidation Reduction Potential (ORP), metals, nitrates, chlorides and sulphates profiles along the column. Results: This test allowed simulating the solid-liquid contact characteristic of a real PRB behavior that proved to be a possible solution for the remediation of inorganic pollutants in groundwater. Conclusion: The considered material showed efficiency above $99 \%$ in metals removal, although further tests, involving biotic processes and more reducing conditions, are necessary to improve the degradation of sulphates and nitrates.
\end{abstract}

Key words: Zero-valent iron, permeable reactive barrier, acid mine drainage, groundwater remediation

\section{INTRODUCTION}

The origins of Acid Mine Drainage (AMD) are well known: pyrite and other sulphide minerals, exposed to an aquatic environment in presence of oxygen and oxidising bacteria produce heavily acidic solutions containing heavy metals and sulphates, that may produce the disappearance of aquatic life, a rust coating in river bottoms and $\mathrm{pH}$ values non tolerable by most crops and fauna. Typical AMD compositions, deriving from sulphide and coal mines are shown in Table $1^{[1]}$. A surface water impacted by AMD is identified by a low $\mathrm{pH}$, typically between 2 and 4 and a high concentration of iron, sulphates, Total Dissolved Solids (TDS) and heavy metals. Otherwise groundwater impacted by AMD is typically less acidic and more reducing because of the buffering influence of hydroxide, carbonate and alumino-silicate minerals occurring in aquifers and due to the consumption of dissolved oxygen and the exclusion of air in subsurface environments.
Table 1: Chemical composition of the polluted aqueous phase employed in this study (referred as column inflow) compared to some AMDs

\begin{tabular}{|c|c|c|c|}
\hline Parameter & $\begin{array}{l}\text { Coal mines } \\
\text { AMD* }\end{array}$ & $\begin{array}{l}\mathrm{Fe}-\mathrm{Cu}-\mathrm{Pb}-\mathrm{Zn} \\
\text { sulphide mines AMD* }\end{array}$ & $\begin{array}{l}\text { Column } \\
\text { inflow }\end{array}$ \\
\hline $\mathrm{pH}$ & $2.6-6.3$ & $2.0-7.9$ & 2.600 \\
\hline ORP (mV) & & & 642.000 \\
\hline $\mathrm{Al}\left(\mathrm{mg} \mathrm{L}^{-1}\right)$ & $1-58$ & & 6.100 \\
\hline $\mathrm{Ba}\left(\mathrm{mg}^{-1}\right)$ & & & 0.126 \\
\hline $\mathrm{Ca}\left(\mathrm{mg} \mathrm{L}^{-1}\right)$ & & & 249.000 \\
\hline $\mathrm{Cu}\left(\mathrm{mg} \mathrm{L}^{-1}\right)$ & & $0.005-76$ & 0.197 \\
\hline $\mathrm{Cr}\left(\mathrm{mg} \mathrm{L}^{-1}\right)$ & & & 0.119 \\
\hline $\mathrm{Fe}\left(\mathrm{mg} \mathrm{L}^{-1}\right)$ & $1-473$ & $8.5-3200$ & 87.000 \\
\hline $\mathrm{K}\left(\mathrm{mg} \mathrm{L}^{-1}\right)$ & & & 9.300 \\
\hline $\mathrm{Mg}\left(\mathrm{mg} \mathrm{L}^{-1}\right)$ & & & 252.000 \\
\hline $\operatorname{Mn}\left(\mathrm{mg} \mathrm{L}^{-1}\right)$ & $1-130$ & 0.4 & 12.500 \\
\hline $\mathrm{Na}\left(\mathrm{mg} \mathrm{L}^{-1}\right)$ & & & 2040.000 \\
\hline $\mathrm{Pb}\left(\mathrm{mg} \mathrm{L}^{-1}\right)$ & & $0.02-90$ & 0.960 \\
\hline $\mathrm{Zn}\left(\mathrm{mg} \mathrm{L}^{-1}\right)$ & & $0.04-1600$ & 10.800 \\
\hline $\mathrm{Cl}^{-}\left(\mathrm{mg} \mathrm{L}^{-1}\right)$ & & & 401.000 \\
\hline $\mathrm{SO}_{4}^{2-}\left(\mathrm{mg} \mathrm{L}^{-1}\right)$ & & & 2614.000 \\
\hline $\mathrm{NO}^{3-}\left(\mathrm{mg} \mathrm{L}^{-1}\right)$ & & & 1212.000 \\
\hline
\end{tabular}

Corresponding Author: Silvia Fiore, DITAG-Department of Land, Environment and Geo-Engineering, Politecnico di Torino, Corso Duca Degli Abruzzi 24, 10129 Torino, Italy Tel: +39/011/5647613 Fax: +39/011/5647699 
Permeable Reactive Barriers (PRBs) are employed in a passive approach to remove inorganic pollutants from groundwater ${ }^{[2]}$. The main challenge is actually the choice of a reactive medium that may be effectively employed in a long term remediation action and also maintains a good hydraulic conductivity. Reactive materials of possible application are essentially made of organic substance, mainly compost, or of non toxic and easily oxidizable metal, among which the most employed is Zero-Valent Iron (ZVI). In barriers rich of organic substances (i.e., wastewater treatment sludge, compost) an anaerobic biomass takes place, thus favouring the life of sulphate reducing bacteria.

Sulphides production that comes from sulphate reduction determines the abatement of heavy metals present in solution as sulphides (usually having a very low solubility) and an alkalinity enhancement.

ZVI materials are characterized by a high degradation efficiency towards heavy metals as chromium, uranium, arsenic, manganese and zinc ${ }^{[3-5]}$. The involved removal mechanisms foresee both the adsorption on the reactive material surface and the metallic hydroxide precipitation. ZVI in contact with water and dissolved oxygen is corroded and oxidised to Fe (II) (Fig. 1 and 2) creating a reducing environment and enhancing alkalinity ${ }^{[7]}$; moreover if proper $\mathrm{pH}$ and ORP conditions happen (Fig. 2), ferrous ion may be further oxidised to Fe (III). Many dissolved species,

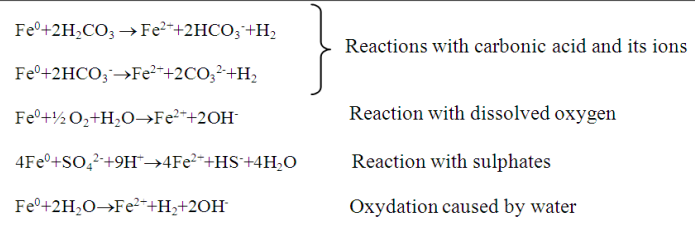

Fig. 1: Some reactions due to groundwater chemistry involving ZVI corrosion

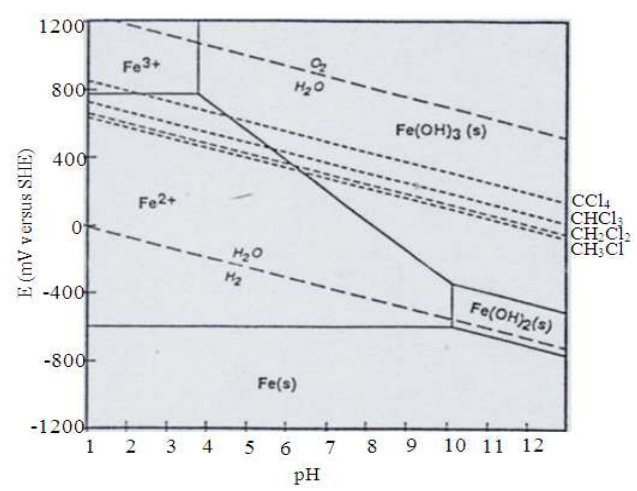

Fig. 2: $\mathrm{Eh} / \mathrm{pH}$ diagram concerning $\mathrm{Fe}^{0}-\mathrm{H}_{2} \mathrm{O}$ system at $15^{\circ} \mathrm{C}^{[6]}$ such as carbonic acid, bicarbonates and sulphates may accelerate ZVI corrosion (Fig. 1) ${ }^{[8-12]}$. Carbonates coming out from the above mentioned reactions generate insoluble precipitates with some metallic ions, such as iron, calcium and magnesium: Moreover, in consequence of the $\mathrm{pH}$ enhancement due to corrosion reactions happening on the reagent substrate, some metallic ions in aqueous phase, eventually deriving from the reagent substrate, may precipitate as hydroxides ${ }^{[13]}$. Such hydroxides, precipitating on the reagent material surface, form a protective layer that prevents a further oxidation.

The above described processes have a negative influence on ZVI PRBs efficiency: $\mathrm{pH}$ increase and reagent material corrosion are intensely accelerated if groundwater has a high content of dissolved salts. Therefore, particularly in a long term, the PRB effectiveness decreases mainly because of the following two aspects:

- Iron corrosion implies a macroscopic dissolution of the metal, thus decreasing the surface area available for the contaminated plume passing through the reactive medium

- An extensive hydroxide layer prevents iron oxidation, thus decreasing the reactive material efficiency

Moreover a ZVI PRB determines important changes in the groundwater physic-chemical properties, thus producing a heavy modification of its chemistry:

- The $\mathrm{pH}$ increase, influencing the formation equilibria of the hydroxides of many metals, eventually released by the reagent material

- The ORP decrease, involving the creation of a reducing environment and affecting the formation equilibria of metallic sulphides

The processes concerning the pollutants removal efficiency and the effects on $\mathrm{pH}$, ORP and the groundwater composition should be considered in the evaluation of the potential of a ZVI material for the remediation of a AMD polluted site. Careful laboratory tests should be devoted to the study of pollutants degradation kinetic aspects, to the estimate of the PRB thickness necessary to remove all the contaminants and to the evaluation of the eventual impact of the ZVI material on groundwater.

The removal efficiency of a granular ZVI material (Brown size 8/50, Peerless Powders and Abrasive Inc., Detroit, US) towards the typical pollutants of a AMD is tested in this preliminary study, to evaluate the 
Am. J. Environ. Sci., 5 (4): 556-561, 2009

applicability of a ZVI PRB for the remediation of a AMD contaminated site located in central Italy. ORP, $\mathrm{pH}$, metals ( $\mathrm{Al}, \mathrm{Ba}, \mathrm{Ca}, \mathrm{Cu}, \mathrm{Cr}, \mathrm{Fe}, \mathrm{K}, \mathrm{Mg}, \mathrm{Mn}, \mathrm{Na}, \mathrm{Pb}$, $\mathrm{Zn}$ ), nitrates, chlorides and sulphates values were monitored during a leaching column test performed employing an aqueous phase reproducing the groundwater composition of the considered polluted site. The aqueous phase was sampled at different distances from the column head after the achievement of steady state conditions and the fluido-dynamic parameters were gathered during a tracer test performed immediately after the sampling operations.

\section{MATERIALS AND METHODS}

AMD solution and reagent material: The aqueous phase employed in the column test $(60 \mathrm{l})$ was prepared adding $96 \% \mathrm{H}_{2} \mathrm{SO}_{4}$ until pH 2.6 to a $0.10 \mathrm{M} \mathrm{Na}_{2} \mathrm{SO}_{4}$, $0.2 \mathrm{M} \mathrm{Fe}\left(\mathrm{NO}_{3}\right)_{3}, 0.05 \mathrm{M} \mathrm{Al}(\mathrm{OH})_{3}$ solution. Solutions of the different metals were prepared from their salts (Sigma-Aldrich) and added to the aqueous phase. The chemical composition of the obtained AMD solution, compared in Table 1 with other $\mathrm{AMDs}^{[1]}$, was experimentally verified as described below.

The ZVI material (Brown size 8/50, Peerless Powders and Abrasive Inc., Detroit, USA) was characterized by means of particle-size and chemical analyses (Table 2). The chemical characterization of the reagent material was performed by means of an acid digestion in a Milestone 1200 Mega microwave oven with $32 \% \mathrm{HCl}$ and $65 \% \mathrm{HNO}_{3}$ The carbon content was determined by means of a Carlo Erba CHNS-O Elemental Analyzer EA 1108.

Experimental test setup: The test was carried out in a Perspex cylinder $\left(1 \mathrm{~m}\right.$ length, $4 \cdot 10^{-2} \mathrm{~m}$ internal diameter), filled with $2.5 \cdot 10^{-2} \mathrm{~m}$ of fine gravel, $95.0 \cdot 10^{-2} \mathrm{~m}$ of ZVI material and $2.5 \cdot 10^{-2} \mathrm{~m}$ of fine gravel. The column is equipped with 8 sampling ports at the distance of $510^{-3}, 810^{-2}, 2.0510^{-1}, 3.5510^{-1}$, $5.0510^{-1}, 6.5510^{-1}, 8.0510^{-1}, 9.3010^{-1} \mathrm{~m}$ from the beginning of the reagent substrate. The liquid phase was fed upwards by means of a ISMATEC ISM 827 with a flow rate of $0.06 \mathrm{l} \mathrm{h}^{-1}$, with reference to the considered polluted site. The sampling operations were performed after the flow of $70 \mathrm{p}$ ore volume (about 5 weeks from the start) and the steady state conditions were verified by means of a tracer test. Five $\mathrm{mL}$ of aqueous phase were sampled by means of a glass syringe, respecting the column flow rate, from each sampling port and also the inflow and outflow were collected.
Table 2: Brown size 8/50 ZVI characterization

\begin{tabular}{ll}
\hline Parameter & New reagent \\
\hline $\mathrm{Ba}\left(\mathrm{mg} \mathrm{kg}^{-1}\right)$ & $<2$ \\
$\mathrm{Ca}\left(\mathrm{mg} \mathrm{kg}^{-1}\right)$ & 175 \\
$\mathrm{Cu}\left(\mathrm{mg} \mathrm{kg}^{-1}\right)$ & 2147 \\
$\mathrm{Cr}\left(\mathrm{mg} \mathrm{kg}^{-}\right)$ & 505 \\
$\mathrm{Fe}(\%)$ & 83 \\
$\mathrm{~K}\left(\mathrm{mg} \mathrm{kg}^{-1}\right)$ & $<2$ \\
$\mathrm{Mg}\left(\mathrm{mg} \mathrm{kg}^{-1}\right)$ & 61 \\
$\mathrm{Mn}\left(\mathrm{mg} \mathrm{kg}^{-1}\right)$ & 3760 \\
$\mathrm{Na}\left(\mathrm{mg} \mathrm{kg}^{-1}\right)$ & 319 \\
$\mathrm{~Pb}\left(\mathrm{mg} \mathrm{kg}^{-1}\right)$ & 87 \\
$\mathrm{Zn}\left(\mathrm{mg} \mathrm{kg}^{-1}\right)$ & 29 \\
$\mathrm{C}(\%)$ & 2.7 \\
bulk density $\left(\mathrm{kg} \mathrm{L}^{-1}\right)$ & 2.71 \\
specific surface area $\left(\mathrm{m}^{-1}\right)$ & 1.90 \\
$\mathrm{D}_{10}, \mathrm{D}_{30}, \mathrm{D}_{50}(\mathrm{~mm})$ & $0.30,0.65,0.85$ \\
\hline
\end{tabular}

Tracer test: The test, performed immediately after the sampling operations by means of a $0.0125 \mathrm{M} \mathrm{KCl}$ solution, allowed the confirmation of the steady state conditions and the achievement of the hydrodynamic parameters of the column $\left(\mathrm{D}_{\mathrm{L}}=0.2310^{-6} \mathrm{~m}^{2} \mathrm{sec}^{-1}\right.$, $\left.\eta_{\text {eff }}=0.63, v_{\mathrm{e}}=2.1 \quad 10^{-5} \mathrm{~m} \mathrm{sec}^{-1}\right)$. The researchers described the tracer test procedure in a previous study $^{[14]}$.

Chemical analyses: Metals $(\mathrm{Al}, \mathrm{Ba}, \mathrm{Ca}, \mathrm{Cu}, \mathrm{Cr}, \mathrm{Fe}$, $\mathrm{K}, \mathrm{Mg}, \mathrm{Mn}, \mathrm{Na}, \mathrm{Pb}, \mathrm{Zn}$ ), nitrates, chlorides and sulphates contents were analysed employing reference procedures $^{[15]}$. A Perkin-Elmer Optima 2000 ICP-OES was employed for the metals analysis and a UVVisible Unicam Helios $\alpha$ spectrometer was used for the ions.

\section{RESULTS}

The results of Brown size 8/50 ZVI material characterization are schematized in Table 2.

The profiles of ORP and $\mathrm{pH}$, nitrates, sulphates and chlorides and of some metals (aluminum, copper, chromium, iron, lead, manganese, nickel and zinc) along the column, obtained considering a mass balance equation of a plug flow reactor and assuming a first order kinetic ${ }^{[14]}$ are plotted in Fig. 3-5 as a function of the residence time, obtained for each sampling port by multiplying the distance from the beginning of the reagent substrate for the aqueous phase seepage velocity (i.e., $t=0$ corresponds to the first sampling port).

The chemical composition of the inflow and the outflow of the column are compared with Italian law (D. Lgs 152/2006) requirements in Table 3. 
Am. J. Environ. Sci., 5 (4): 556-561, 2009

Table 3: Chemical composition of the column inflow and outflow and Italian law limits (D Lgs 152/2006) concerning groundwater

\begin{tabular}{llll}
\hline Parameter & Column inflow & Column outflow Italian law limits \\
\hline $\mathrm{pH}$ & 2.60 & 9.49 & $5.5-9.5$ \\
$\mathrm{ORP}(\mathrm{mV})$ & 642 & 192 & - \\
$\mathrm{Al}\left(\mathrm{mg} \mathrm{L}^{-1}\right)$ & 6.1 & $<0.003$ & 1 \\
$\mathrm{Ba}\left(\mu \mathrm{g} \mathrm{L}^{-1}\right)$ & 126 & $<13$ & 20000 \\
$\mathrm{Ca}\left(\mathrm{m} \mathrm{L}^{-1}\right)$ & 249 & 243 & - \\
$\mathrm{Cu}\left(\mu \mathrm{g} \mathrm{L}^{-1}\right)$ & 197 & 63 & 100 \\
$\mathrm{Cr}\left(\mu \mathrm{g} \mathrm{L}^{-1}\right)$ & 119 & $<7$ & 2000 \\
$\mathrm{Fe}\left(\mathrm{mg} \mathrm{L}^{-1}\right)$ & 87 & $<0.0005$ & 2 \\
$\mathrm{~K}\left(\mathrm{~m} \mathrm{~L}^{-1}\right)$ & 9.3 & 15.1 & - \\
$\mathrm{Mg}\left(\mathrm{mg} \mathrm{L}^{-1}\right)$ & 252 & 296 & - \\
$\mathrm{Mn}\left(\mu \mathrm{g} \mathrm{L}^{-1}\right)$ & 12500 & 24.7 & 2000 \\
$\mathrm{Na}\left(\mathrm{mg} \mathrm{L}^{-1}\right)$ & 2040 & 2100 & - \\
$\mathrm{Pb}\left(\mu \mathrm{g} \mathrm{L}^{-1}\right)$ & 959 & $<4$ & 200 \\
$\mathrm{Zn}\left(\mu \mathrm{g} \mathrm{L}^{-1}\right)$ & 10800 & $<2$ & 500 \\
$\mathrm{Cl}^{-}\left(\mathrm{mg} \mathrm{L}^{-1}\right)$ & 401 & 629 & 1200 \\
$\mathrm{SO}_{4}^{2-}\left(\mathrm{mg} \mathrm{L}^{-1}\right)$ & 2614 & 1628 & 250 \\
$\mathrm{NO}^{3-}\left(\mathrm{mg} \mathrm{L}^{-1}\right)$ & 1212 & 808 & 88 \\
\hline
\end{tabular}

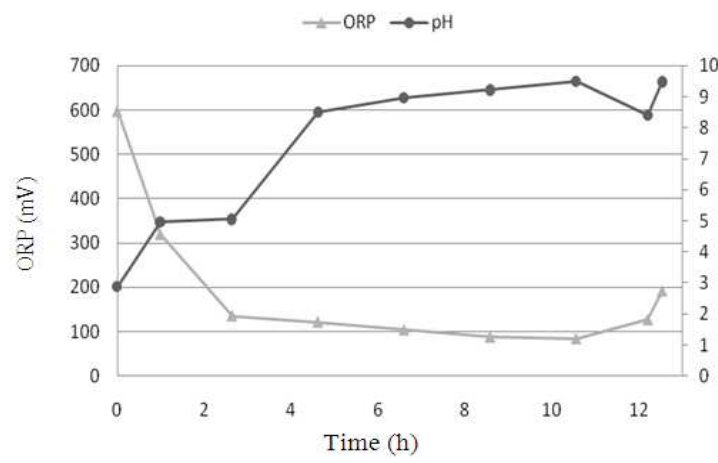

Fig. 3: ORP and $\mathrm{pH}$ profiles along the column

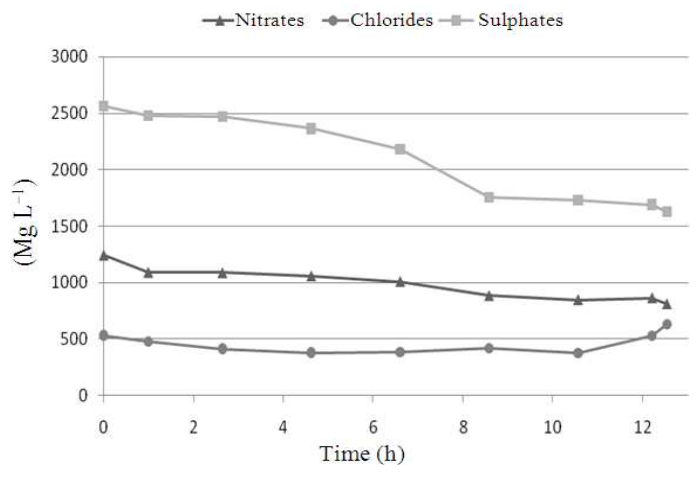

Fig. 4: Nitrates, sulphates and chlorides profiles along the column

The first order kinetic constants values calculated from the experimental results considering the removal of aluminum, iron, lead, manganese and zinc from the polluted aqueous phase are displayed in Table 4.
Table 4: First order kinetic constant values calculated from the column test results

\begin{tabular}{ll}
\hline Pollutant & $\mathrm{k}\left(\mathrm{sec}^{-1}\right)$ \\
\hline $\mathrm{Al}$ & $5.0 \cdot 10^{-3}$ \\
$\mathrm{Fe}$ & $2.7 \cdot 10^{-4}$ \\
$\mathrm{Mn}$ & $1.2 \cdot 10^{-4}$ \\
$\mathrm{Zn}$ & $5.6 \cdot 10^{-4}$ \\
$\mathrm{~Pb}$ & $1.0 \cdot 10^{-4}$ \\
\hline
\end{tabular}

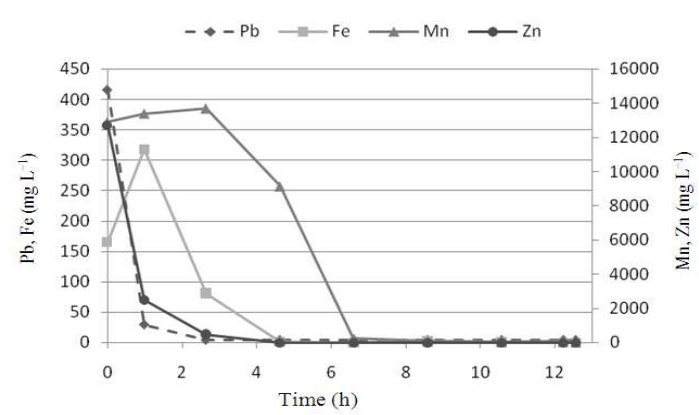

(a)

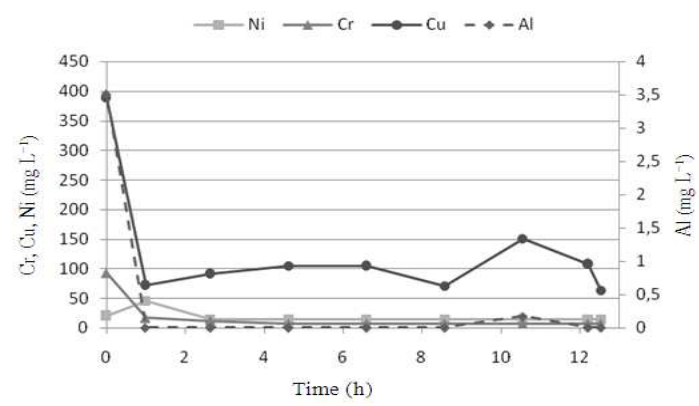

(b)

Fig. 5: Metals profiles along the column (a): $\mathrm{Pb}, \mathrm{Fe}, \mathrm{Mn}$ and $\mathrm{Zn}$; (b): $\mathrm{Al}, \mathrm{Ni}, \mathrm{Cu}, \mathrm{Cr}$

\section{DISCUSSION}

The tested ZVI reagent substrate shows the typical composition of a cast iron material (Table 2) and it is made of scraps having dimensions between 0.12 and $1.2 \mathrm{~mm}$ (particle-size curve not shown).

All the outflow parameters (Table 3), nitrates and sulphates excepted, fulfill the requirements of Italian law concerning groundwater.

ORP and $\mathrm{pH}$ profiles along the column (Fig. 3) show a $\mathrm{pH}$ increase and a ORP decrease, respectively from $2.6 \mathrm{pH}$ units and $642 \mathrm{mV}$ in the inflow to $9.5 \mathrm{pH}$ units and $192 \mathrm{mV}$ in the outflow, according to the corrosion processes involving ZVI connected with the removal of metals and the contact with water (Fig. 1). The slope of both profiles rises after the sampling port No. 2 (at $0.075 \mathrm{~m}$ height of the reagent material column, corresponding to a residence time equal to $0.99 \mathrm{~h}$ in the considered boundary conditions). The highest $\mathrm{pH}$ value 
and the lowest ORP value are reached at the sampling port No. 7 (at $0.8 \mathrm{~m}$ height of the reagent material column, corresponding to a residence time equal to $10.56 \mathrm{~h}$ ), afterwards the profiles become opposite, that is the $\mathrm{pH}$ decreased and the ORP increased, probably due to the formation of a layer of corrosion products which reduced the specific surface area of the reagent substrate.

Nitrates profile (Fig. 4) shows a progressive decrease, particularly after No. 2 sampling port (corresponding to a ORP equal to $320 \mathrm{mV}$, that allows nitrates reduction $\left.{ }^{[16]}\right)$, but Italian law requirements are not satisfied.

Sulphates profile (Fig. 4) also shows a constant decline due to the abiotic reaction reported in Fig. 1. Actually, at the ORP values measured along the column the sulphate reduction to sulphide isn't possible. Sulphates concentration, equal to $1628 \mathrm{mg} \mathrm{L}^{-1}$, in the column outflow doesn't fulfill Italian law requirements, although considering the real performance of a ZVI PRB the sulphates reduction processes would be considerably enhanced by the presence of an organic substrate and sulphate-reducing bacteria ${ }^{[17]}$. The analysis of Fig. 4 experimental data allowed to calculate a first order kinetic constant value equal to $1.0810^{-5} \mathrm{sec}^{-1}$, leading to a necessary thickness of the PRB equal to about $5 \mathrm{~m}$, obviously not realizable, in order to obtain sulphates concentration values below Italian law requirements.

Metals profiles are displayed in Fig. 5. The iron concentration significantly increased until No. 2 sampling port (from 87 in the inflow to $318 \mathrm{mg} \mathrm{L}^{-1}$ ), because of the corrosion processes linked to the metals removal and the contact with water. The ORP and $\mathrm{pH}$ profiles after No. 3 sampling port allow the creation of solid ferric hydroxide (see Figure 2), thus explaining the drastic further decrease of the iron concentration value. The manganese profile is similar: An initial increase until No. 2 sampling port then a drastic inversion, due to $\mathrm{Mn}$ (II) hydroxide formation at $\mathrm{pH}$ values above $8^{[18]}$.

The aluminum content, not influenced by ZVI corrosion, rapidly decreases after No.2 sampling port because of the creation at the corresponding $\mathrm{pH}$ and ORP values of aluminum hydroxide, probably in the gibbsite form ${ }^{[18]}$. It is also possible that adsorption phenomena take part in aluminum removal from the aqueous phase, because $\mathrm{Al}(\mathrm{III})$ is preferably adsorbed compared to other cations having a lower charge.

Zinc, lead, copper and chromium contents, influenced by $\mathrm{pH}$ and ORP profiles, dramatically decrease after No. 2 sampling port due to the formation of the corresponding hydroxides and also possibly because of sorption phenomena and the creation of mixed solid phases by means of co-precipitation processes ${ }^{[16]}$.

Sodium, potassium, calcium and magnesium profiles (data not reported) don't show any relevant variation along the column because the solubility limits of their hydroxides and carbonates are not reached during the test.

First order kinetic constant values obtained for aluminium, iron, manganese, zinc and lead from the analysis of the experimental data are reported in Table 4. The removal efficiency of Brown ZVI material follows the order $\mathrm{Al}>\mathrm{Pb}>\mathrm{Mn}>\mathrm{Fe}>\mathrm{Zn}$. Considering lead, characterized the lowest kinetic constant value, a PRB thickness equal to $0.95 \mathrm{~m}$ was calculated as necessary to obtain the fulfillment of Italian law requirements for all the considered metals.

\section{CONCLUSION}

The evaluation of the connections between a reagent material and the groundwater chemistry and of the linked kinetic aspects is mandatory for a proper dimensioning of a ZVI PRB.

On the grounds of the obtained results, Brown size 8/50 (Peerless Powders and Abrasive Inc.) ZVI material proved its efficiency in the considered inorganic pollutants remediation. Aluminium, iron, manganese, lead and zinc were effectively removed, with percentages varying from $99.6-99.9 \%$, by means of the creations of insoluble hydroxides and also involving adsorption processes on the negative charged surface of the substrate.

Sulphates and nitrates contents weren't lowered below Italian law requirements during the performed column test, which involved predominantly abiotic processes. In real environments, due to the naturally present bacteria and particularly in PRB containing organic material, biotic processes may lead to the desired removal of nitrates and sulphates. Further tests are necessary to evaluate these aspects and to improve nitrates and sulphates removal efficiency of the considered ZVI material.

\section{REFERENCES}

1. Gazea, B., K. Adam and A. Kontopoulos, 1996. A review of passive systems for the treatment of acid mine drainage. Miner. Eng., 9: 23-42. http://cat.inist.fr/?aModele=afficheN\&cpsidt=2950657

2. Blowes, D.W., C.J. Ptacek, G.B. Benner, W.T. McRae, T.A. Bennett and R.W. Puls, 2000. Treatment of inorganic contaminants using permeable reactive barriers. J. Contam. Hydrol., 45: 123-137. http://cat.inist.fr/?aModele=afficheN\&cpsidt=1470820 
3. Cantrell, K.J., D.I. Kaplan and T.W. Wietma, 1995. Zero-valent iron for the in situ remediation of selected metals in groundwater. J. Hazar. Mater., 42: 201-212.

http://cat.inist.fr/?aModele $=$ afficheN\&cpsidt $=3606$ 246

4. Lackovic, J.A., N.P. Nickolaidis and G.M. Dobbs, 2000. Inorganic arsenic removal by zero-valent iron. Environ. Eng. Sci., 17: 29-39. DOI: 10.1089/ees.2000.17.29

5. Morrison, S.J., R.R. Spangler, 1993. Chemical barriers for controlling groundwater contamination. Environ. $\quad$ Prog., 12: 175-181. http://cat.inist.fr/?aModele=afficheN\&cpsidt $=4890453$

6. Beverskog, B. and I. Puigdomenech, 1996. Revised pourbaix diagrams for iron at $25-300^{\circ} \mathrm{C}$. Corrosion Sci., 38; 2121-2135. DOI: 10.1016/S0010938X(96)00067-4

7. Gillham, R.W. and S.F. O'Hannesin, 1994. Enhanced degradation of halogenated aliphatics by zero-valent iron. Ground Water, 32: 958-967. DOI: 10.1111/j.1745-6584.1994.tb00935.x

8. Agrawal, A., W.J. Ferguson, B.O. Gardner, J.A. Christ and P.G. Tratnyek, 2002. Effects of carbonate species on the kinetics of dechlorination of 1, 1, 1trichloroethane by zero-valent iron. Environ. Sci. Technol., 36: 4326-4333. http://www.ncbi.nlm.nih.gov/pubmed/12387405

9. Gotpagar, J., E. Grulke, T. Tsang and D. Bhattacharyya, 1997. Reductive dehalogenation of trichloroethylene using zero-valent iron. Environ. Prog., 16: 137-143. DOI: 10.1002/ep.3300160221

10. Matheson, L.J., P.G. Tratnyek, 1994. Reductive dehalogenation of chlorinated methanes by iron metal. Environ. Sci. Technol., 28: 2045-2053. http://pubs.acs.org/doi/abs/10.1021/es00061a012

11. Cheng, S. and S. Wu, 2001. Feasibility of using metals to remediate water containing TCE. Chemosphere, 43: 1023-1028. http://www.ncbi.nlm.nih.gov/pubmed/11368216
12. Furukawa, Y., J. Kim, J. Watkins and R.T. Wilkin, 2002. Formation of ferrihydrite and associated iron corrosion products in permeable reactive barriers of zero-valent iron. Environ. Sci. Technol., 36: 5469-5475.

http://www.ncbi.nlm.nih.gov/pubmed/12521177

13. Vogan, J.L., R.M. Focht, D.K. Clark and S.L. Graham, 1999. Performance evaluation of a permeable reactive barrier for remediation of dissolved chlorinated solvents in groundwater. J. Hazar. Mater. 68, 97-108. http://www.ncbi.nlm.nih.gov/pubmed/10518666

14. Zanetti, M.C. and S. Fiore, 2005. Evaluation of mutual connections between zero-valent iron reactivity and groundwater composition in the degradation of trichloroethylene. Annali Di Chimica Rome, 95: 779-789. DOI: 10.1002/adic.200590091

15. APHA, AWWA, WPCF, 1999. Standard Methods for the Examination of Water and Wastewater. 20th Edn., APHA, New York, ISBN: 10: 0875532357, pp: 1325.

16. McBride, M.B., 1994. Environmental Chemistry of Soils. Oxford University Press, New York Oxford, ISBN: 10: 0195070119, pp: 416.

17. Benner, S.G., 2000. The hydrogeology, geochemistry and microbiology of a permeable reactive barrier for acid mine drainage. $\mathrm{PhD}$ Thesis, University of Waterloo, Ontario, Canada. http://uwspace.uwaterloo.ca/bitstream/10012/470/1 /NQ51179.pdf

18. Wilkin, R.T. and M.S. McNeil, 2003. Laboratory evaluation of zero-valent iron to treat water impacted by acid mine drainage. Chemosphere, 53: 715-725.

http://cat.inist.fr/?aModele $=$ afficheN\&cpsidt $=1512$ 3718 